Привсденные вышс результаты позволяют сделать вывод, что проростки, пронсхон дяшне из гаплондных множественных почск риса, могут служить хорошим истотни. ком гаплондных протоп.астов. Использи вырапивасмые in itro мнокественныс шитки, можно изнснять способы предобработки н процсдуру культивировання протоп.'астов дия упрощення процессов их нзоляпни и постедующсго кусытивирования. Мы надесыся также, что нзолированные таким способом протоптасты могут быты соноставимы с мсзофнтьными протонтастами, выделеннымн непосрсдствснно из нормалыных н мнтактных растениї, и яв.тяться основой фнзиолонисски н эпигентически гомогеною стсрниьного матсрнала для работы с гаплондными протопластамн в течсние ве(г) года и в любых климатических условнях. Такая систсма, вероятно, персиективна дія риса, з.такового растсния, а также для других растеннй, в том чнсле и двудотьиыл, при модсльных исследованиях in witro.

\title{
A SIMPLE METHOD FOR ISOLATION OF HAPLOID PROTOPLASTS FROM FORMS OF RICE MULTISHOOTS
}

Huthn Xuan Thao, Trinh Manh Dung, Ngo Ke Suong

Institute of Experimental Biology, Ho Chi Minh City, Vietnam

Sum mary

One-month old sterile plantlets grown on the $0.3 \mathrm{M}$ sucrose medium were used for protoplast isolation. The young part of leaves were cut onto small pices (1 mm) and left for over night incubation in the $2 \% \mathrm{v} / \mathrm{v}$ driselase solution containing glucose $0.4 \mathrm{M}$. Isolated protoplasts were purified by two-phase centrifugation (the upper phase contains solution of salts, the lower one-0.4 $\mathrm{M}$ of sucrose and other nutritional constituents). The purified protoplasts were suspended between two phases.

1. Establishment of an efficient medium for anther culture of rice through comparative experiments on nitrogen sources / C. C. Chu, C. C. Wang, C. S. Sun et al.// Sci. Sinica.- 1975.- N 5.- P. $659-668$.

2. King P. J., Potrykus I., Thomas E. In vitro genetics of cereals: problem and perspectives // Physiol. Veg-- 1978.-16, N 2.-P. 381-399.

3. Further studies on plantlet production from cultured tissues of Sorghum bicolor / D. I. Dunstan, K. C. Short, H. Dhaliwal et al. // Protoplasma.- 1979.-101, N 4.P. 355-361.

4. Thomas E., King P. J., Potrykus I. Improvement of crop plants via single cells in vitro - an assessment // Z. Pflanzenzucht. - 1979.-82, N 1.- P. 1-30.

5. Vasil I. K. Regeneration of plants from single cells of cereals and grasses // Genetic engineering in eukaryotes / Eds P. F. Lurquin, A. Kleinhofs.- New York : Plenum Publ. Co., 1983.- P. 233-252.

6. Глеба Ю. Ю., Сытник К. М. Клеточная ннженерия растений.- Қиев: Наук. думка, 1984.- $160 \mathrm{c}$.

7. Murashige T., Skoog F. A revised medium for rapid growth and bioassays with tobacco tissue cultures // Physiol. Plant.-1962.-15, N 4.- P. 473-497.

Ин-т экспсрим. биологии Нац. центра науч, исследований СРВ, Хошимин

По.лучсіо 04.06 .86

уцК $579.887 .111: 579.252$

\section{В ДНК МИКОПЛАЗМ, ОБЛАДАЮЩИХ ПОДВИЖНОСТЬЮ, ОБНАРУЖЕНЫ ФРАГМЕНТЫ, ГОМОЛОГИЧНЫЕ ГЕНУ АКТИНА ЭУКАРИОТ}

\section{О. А. Чернова, Н. А. Меркулова, С. Н. Борхсениус}

Мнкоптазмы-собиратсльнос названис представителсй класса Mollicutes - caмых малых из свободноживущих прокарнотических организмов. Большинство микоплазм симбионты, многис-паразиты, некоторые микоплазмы-возбудители болезней человска, животных, растений $[1,2]$. Как прави.то, они неподвижны, но некоторые патогенные микоплазмы, в частности, Mycoplasma pneumoniae (возбудитель атипичной пнсв- 
онин четовека), Mycoplasma gallisepticum (возбуднтель респнраторных заболсваниї тиц) об:лдают так называсмої скользыщсї подвнжностью, а спнралсвидныс клстли ipiroplasma citri, вызывающей поражения цитрусовых, способны активно вращаться н

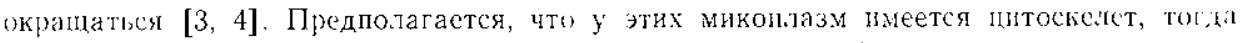
ак среди других прокарнот, включая микопуазмы, не обладаюцие подвнжностьн, нтоскслетонодобныс образования нензвестны $[5,6]$. У всех эукарнот в сохранснин
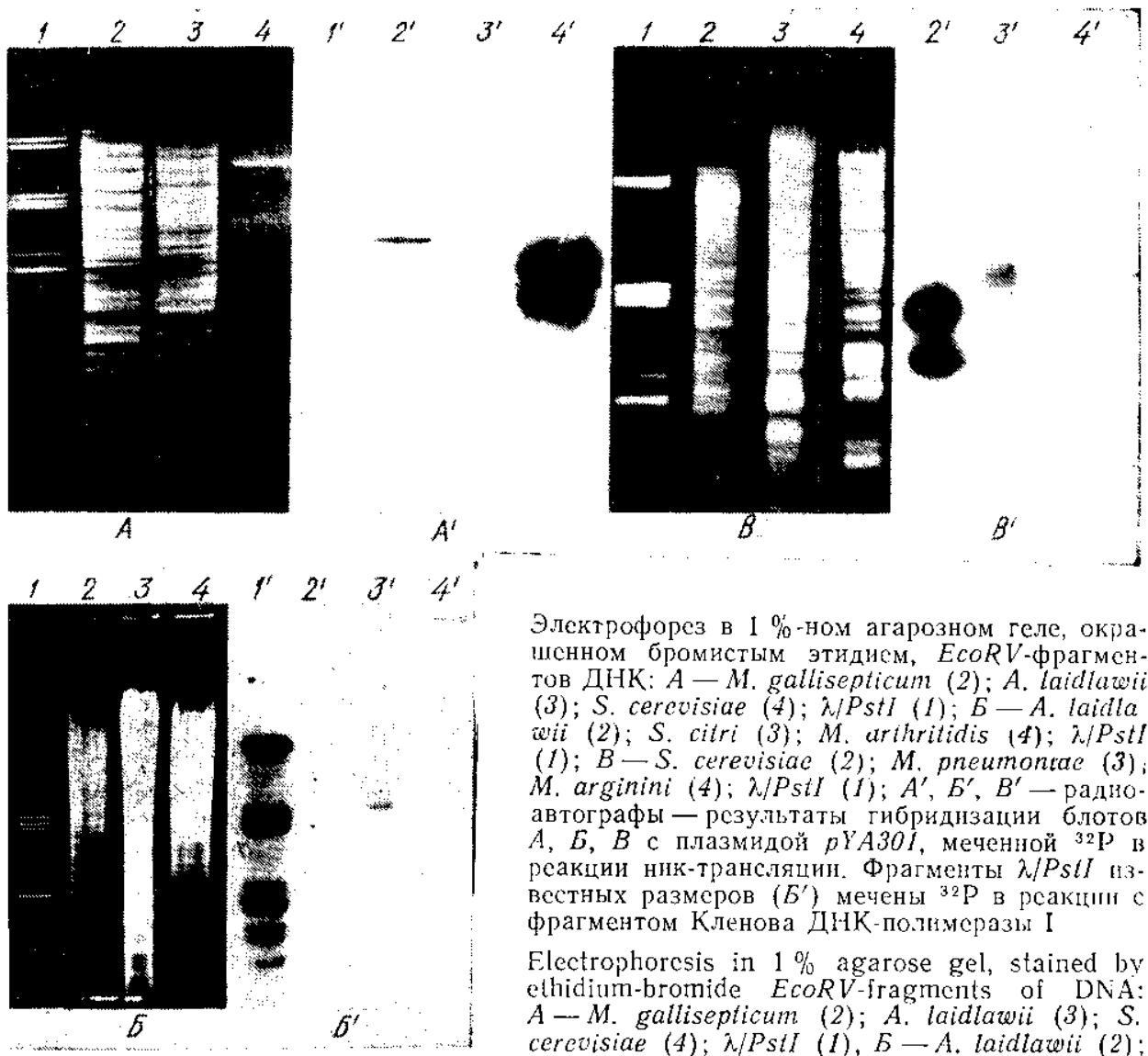

Элсктрофорез в 1 \%-ном агарозном геле, окра. иснном бромистым этидисм, EcoRV-фрагментов ДНК: $A-M$. gallisepticum (2); A. laidlawi (3); S. cercvisiae (4); MPstI (I);E-A. lailla wit (2); S. citri (3);M. arihritidis $(4) ; \lambda / P_{s}$ il (1); $B-S$. cerevisiae (2); $M$. pneumontae (3); $M$. arginini (4); $\lambda / P_{\text {stI }}(1) ; A^{\prime}, 5^{\prime}, B^{\prime}$ - радноавтографы - рсзультаты гибриднзации блотов $A, E, B$ с плазмидой $p Y A 30 \%$, меченной ${ }^{32} \mathrm{P}$ із реакции ннк-трансляцин. Фрагменты ג/Psil $113-$ вестных размеров $\left(D^{\prime}\right)$ мечены ${ }^{32} \mathrm{P}$ в рсакцाг $c$ фрагментом Кленова ДНК-полимсрази I

Electrophoresis in $1 \%$ agarose gel, stained by elhidium-bromide EcoRV-fragments of DNA: $A-M$. gallisepticum (2);A. laidlawii (3); $S$. cercvisiae (4); $M / P$ StI (1), $D-A$. laidlawii (2): S. citri (3); $M$. arthritidis $(4) ; \lambda / P$ sil $(1) ; B-$ $\therefore$ cerevisiae $(2) ; M$. pneumoniae $(3) ; M$. arginini $(4) ; \lambda / P$ st $(I) ; A^{\prime}, \bar{B}^{\prime}, B^{\prime}-$ autoradioraphs... results of hybridization of $A, E, B$ blots with plasmid $p Y A 301$ 32P labelled in he reaction of nick-translation, $\lambda_{2}$ PstI fragments of the known sizes $\left(D^{\prime}\right)$ are ${ }^{32} \mathrm{P}$ labelled n the reaction with Klenow DNA-polymerase I fragment

ормы к.Іетки и кисточном движении принимаст участие цитоскелет, одним из основІых э.лемснтов которого яв.яютея микрофиламенты, содержащие актнн.

11з клеток миколлазм, обладающих подвнжкостью, рансе были выделены актиноюдобныс белкн. Актнноподобный белок $M$. pnémoniae связывается с антнтелами к ұышечному актину кролнка н реагнруст с фаллондином. Бслок с молекуллрной масой 46000 , способный полнмеризоваться в $0,6 \mathrm{M} \mathrm{KCl} \mathrm{н} \mathrm{деполнмеризоваться} \mathrm{в} \mathrm{слабом}$ астворе соли, был выдслен из $M$. gallisepticum. Подвижность $M$. gallisepticum ингиінрустся цитохолозином $B$. Из клеток $S$. citri выделен белок, активно связывающийся аптнтслами к актину беспозвоночных $[4,7-9]$

В ДНК $M$. pneumoniae, $M$. gallisepticum, S. citri нами обнаружены фрагмснты ДНК, гомологичные гену актина дрожжсй. На рисунке представлены данныс по блотибриднзации рестриктазных фрагментов ДНК ряда микоплазм с плазмидой $p Y A 301$, :одержаней ген актина $S$. cerevisiae (плазмида $p$ Ү301 любезно предоставлена Д. Галлитцем, Марбург. ун-т, ФРГ). В ДНК микоплазм, нс обладающих подвнжностью Acholeplasma laidlawit, $M$. arthritidis, M. arginini), фрагменты, гибридизующиеся с этим еном, не обнаружены.

Гнбридизуемость фрагментов генома микоплазм, обладающих подвижностью, : эукариотнческнм геном актнна дрожжсй, позволяет предположнть двс возможности 
появлсния актнноподобиых генов у микоплазм: 1) изначальная общность пронсхождсния актнноподобных молекул; 2) «горнзонтальный перенос» гена от клетки-хозяина к мнколазис, поскольку в природе микоплазмы всегда находятся в тесной связи с клетками хозяев. Микоплазмы растенй и насекомых-внутрнклеточныс паразиты,

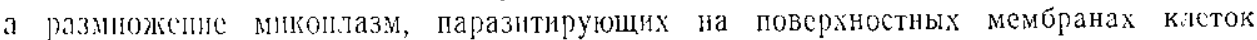
м.лекопнтаюши, покст, по-внднмому, иронсходить как вне, так и внутри клеток [10]. Характер взанмдейстия микоптазмы с клстками хозянна не искаючаст возможности облсла генетитским матерналом [11]; в ряде стучасв изменения клсток под действнем млкоп.лазы при ц.лтельных инфскциях сравнивают с изменениями, продуцирусмыми интемрационными внрусами [12]. Известно, что сайты ДНК, критичные для нитеграцин гирусов, связаны с дпинными концевыми повторами внрусов [13]. ДНК всех провсреніых нами микоплазм содсрхкат фрагменты, гомологичые диинным концсвым повторам внруса Раушера [14].

Сопостансние послсдовательностсй нуклсотидов в клонированных «актнноподобных» носледоватстьностях позволит прояснить природу нх происхождсния в ДНК миконітазм.

\section{THE DETECTION OF THE FRAGMENTS HOMOLOGOUS}

\section{TO EUCARYOTIC $\triangle$ CTIN GENE IN DNAS OF MOBILE MYCOPLASMAS}

O. A. Chernoia, K. A. Merkulova, S. N. Borchsenius

Institute of Cylology, Academy of Sciences of the USSR, Leningrad

Suln in a r y

The fragments homologous to actin gene of Saccharomyces cereuisiae have been revealed in DNAs of mobile mycoplasmas (procaryotic organisms): Mycoplasma pneumo. niae, Mycoplasma gallisepticum, Spiroplasma citri. The fragments homologous to actin gene of Saccharomyces cerevisiae have not been revealed in DNAs of immoile mycoplasmas.

The presence of such fragments in DNAs of mycoplasmas can be consequence of common origin of actin-like molecules in cells of different organisms or "horizontal transfer" of actin gene (from host cell to mycoplasma cell).

1. Борхсниус C. И., Уернова O. А. Мноплазмы//Цитология.- 1987.-29, № 4 C. $379-390$

2. Razin S. Molecular biology and genetics of Mycoplasmas (Mollicutes) // Microbiol. Rev.--1985.-..49, N 4.-P. 419-455.

3. Bove J. M., Saillard C. Cell biology of spiroplasmas. Motility // The mycoplasmas.New Yort: Acad. press, 1979.-Vol. 3.- P. 120-133.

4. Bredt W. Motility // Ibid.- Vol. 1.-P. 141-156.

5. Kahane I., Granek J., Reisch-Soad A. The adhesions of Mycoplasma gallisepticum and W. pnemoniac // Ann. Microbiol- 1984-135A. - P. 25-32.

6. Townsend R., Bargess J. Plaskitt K. A. Morphology and ultrastructure of helical and nonliclical strains of Spiroplasma citri// J. Bacteriol-1980.-142, N 3.P. $973-981$

‘. Göbel U. Supramolecular structures in Mycoplasmas //Yale J. Biol. Med.- 1983.56, N 5-6.-P. 695-700

8. Maniloff J., Chaudhuri $U$. Gliding mycoplasmas are inhibited by cytohalasin $B$ and contain a polymerizable protein fraction// J. Supramol. Struct.-1979.- 12, N 3.P. $299-304$

9. Neimark 11. Mycoplasma and bacterial proteins resembling contractile proteins: a review // Yale J. Biol. Med. - 1983.-56, N 5-6.- P. 419-423.

10. Прозоровский C. В., Промин $A$. B., Санин А. В. Иммунологнческие механизмы перснстенции микошлазм // Вестн. АМН СССР.-1985.-№ 10.-C. 43-51.

11. Каган $\Gamma$ 9. Микоплазмология - новая отрасль микробиологин $/ /$ Микробнол. журн.-1981.-43, № 3.- C. 393-404.

12. Fogh J., Fogh $H$. Chromosomal changes in cell culture induced by mycoplasma infection // Ann. N. Y. Acad. Sci.-1973.-225- P. 311-319.

13. Хесин P. Б. Непостоянство генома.- M. : Наука, 1985.472 с.

14. Геном микоплазм: оценка возможности «горизонтального» переноса фрагментов ДНК / С. Н. Борхсениус, О. А. Чернова, Н. А. Меркулова, А. Ф. Арэ // Тез. Всесоюз. онохим. съезда.- Киев, 1986.- Т. 2.- С. 347.

Ин-т цитологни АН СССР, Ленинград

Получено 15.12 .86 